\title{
BRAZILIAN NETWORK FOR NURSING AND PATIENT SAFETY: CHALLENGES AND PERSPECTIVES
}

\author{
Graziela Caldana ${ }^{1}$ Edinêis de Brito Guirardello², Janete de Souza Urbanetto³, Maria Angélica Sorgini \\ Peterlini ${ }^{4}$, Carmen Silvia Gabriel ${ }^{5}$
}

\begin{abstract}
${ }^{1}$ Doctoral student, Programa de Enfermagem Fundamental, Escola de Enfermagem de Ribeirão Preto, Universidade de São Paulo (EERP/ USP). Ribeirão Preto, São Paulo, Brazil. E-mail: graziela.caldana@usp.br

${ }^{2}$ Ph.D. in Nursing. Associate Professor, Faculdade de Enfermagem, Universidade Estadual de Campinas. Campinas, São Paulo, Brazil. E-mail: guirar@fcm.unicamp.br

${ }^{3}$ Ph.D. in Health Sciences. Professor, Faculdade de Enfermagem Fisioterapia e Nutrição, Pontifícia Universidade Católica Rio Grande do Sul. Porto Alegre, Rio Grande do Sul, Brazil. E-mail: jurbanetto@pucrs.br

${ }^{4}$ Ph.D. in Nursing. Associate Professor, Departamento de Enfermagem Pediátrica, Escola Paulista de Enfermagem, Universidade Federal de São Paulo. São Paulo, São Paulo, Brazil. E-mail: maria.angelica@unifesp.br

${ }^{5}$ Ph.D. in Public Health Nursing. Professor at EERP/USP. Ribeirão Preto, São Paulo, Brazil. E-mail: cgabriel@eerp.usp.br
\end{abstract}

\begin{abstract}
This study's aim was to describe the experience of implementing the Brazilian Network for Nursing and Patient Safety, as well activities intended to disseminate a culture of patient safety in health and educational institutions. This is an experiment report. The Brazilian Network was completed six years ago and, since its establishment, has promoted actions always in consonance with the objectives of the International Network for Nursing and Patient Safety and the World Alliance for Patient Safety. Networks proposed by the Pan American Health Organization corroborated the actions taken by the Brazilian Network. These actions have been successful, as every year new members are added and new Centers are established, while the Network has participated in academic, scientific and government activities. The challenge lies in increasing the impact of these actions to implement safe practices effectively in healthcare facilities.
\end{abstract}

DESCRIPTORS: Patient safety. Nursing. Quality assurance health care. Quality of health care.

\section{REDE BRASILEIRA DE ENFERMAGEM E SEGURANÇA DO PACIENTE: DESAFIOS E PERSPECTIVAS}

RESUMO: O estudo objetivou descrever a experiência da implementação da Rede Brasileira de Enfermagem e Segurança do Paciente, bem como as atividades desenvolvidas a fim de disseminar a cultura de segurança do paciente em instituições de saúde e de ensino. Trata-se de um relato de experiência. A Rede completou seis anos e, desde a sua criação, vem realizando ações em consonância com os objetivos da Rede Internacional de Enfermagem e Segurança do Paciente e a Aliança Mundial para Segurança do Paciente. Entendese que o trabalho em Redes, proposto pela Organização Pan-Americana da Saúde, corroborou com as ações realizadas pela Rede no Brasil, que podem ser consideradas exitosas, tendo em vista que a cada ano há inserção de novos membros, abertura de novos Polos e Núcleos, e a participação da Rede em atividades acadêmicas, científicas e governamentais. O desafio está no aumento do impacto dessas ações com vistas à efetivação da prática segura nas instituições de saúde.

DESCRITORES: Segurança do paciente. Enfermagem. Garantia da qualidade dos cuidados de saúde. Qualidade da assistência à saúde.

\section{LA RED BRASILERA DE ENFERMERÍA Y SEGURIDAD DEL PACIENTE: DESAFÍOS Y PERSPECTIVAS}

RESUMEN: Este estudio tiene como objetivo describir la experiencia de la implementación de la Red Brasileña de Enfermería y Seguridad del Paciente, así como las actividades realizadas para difundir la cultura de seguridad del paciente en las instituciones de salud y de enseñanza. Se trata de un relato de experiencia. La Red tiene seis años. Desde sus inicios viene desarrollando acciones siempre en consonancia con los objetivos de la Red Internacional de Enfermería y Seguridad del Paciente y la Alianza Mundial para la Seguridad del Paciente. Se entiende que el trabajo en redes propuestas por la Organización Panamericana de la Salud corroboró las medidas adoptadas por la Red Brasileña que pueden considerarse un éxito, teniendo en cuenta que, cada año se da la inclusión de nuevos miembros, la apertura de nuevos polos y núcleos y la participación de la Red en actividades académicas, científicas y gubernamentales. El desafío consiste en aumentar el impacto de este tipo de acciones con el fin de efectuar la práctica segura en las instituciones de salud. DESCRIPTORES: Seguridad del paciente. Enfermería. Garantía de la calidad de atención de salud. Calidad de la atención de salud. 


\section{INTRODUCTION}

Patient safety can be defined as the absence of potential or unnecessary harm to patients associated with healthcare delivery and the ability of healthcare facilities to adapt to human and operational risks inherent to the work process. ${ }^{1}$

Ensuring quality healthcare services implies processes that ensure that clinical care meets established criteria or standards. Some of the basic principles of quality are continuous prevention and improvement. ${ }^{2}$

Concerns related to "Patient Safety" have been on the agenda since 1863 when Florence Nightingale expressed such a concern in her book "Notes on hospitals". Great advancement took place in the 1990s when James Reason made an important contribution to the understanding of how mistakes occur when he highlighted that mistakes are a result of a failure in the system and for this reason should be addressed from a holistic point of view. ${ }^{3}$

Reason's studies became known in 1999 with the Institute of Medicine (IOM) report, titled: To err is human: building safer healthcare, which generated a great impact and strongly influenced the world movement toward patient safety. ${ }^{4}$ The report drew the health institutions' attention to the need to strengthen the culture of safety at an organizational level, as a measure essential to the process of improving patient safety in the hospital context. ${ }^{5}$ Achieving sustainable improvements in patient safety, however, can be difficult. Specific measures, as well as professional training, teamwork and the establishment of facilities prepared to ensure patient safety have been associated with improvement in the culture of safety. ${ }^{6}$

In 2004, the World Health Organization (WHO) created the project "World Alliance for Patient Safety", with the objective of drawing attention to the improvement of patient safety within healthcare and to political commitment, in addition to supporting the development of patient safety-related public policies and practices around the world. ${ }^{7}$ Since then, the Pan-American Health Organization (PAHO) has proposed Latin America to cooperate in order to accomplish the actions provided in the "World Alliance for Patient Safety".

One of the actions of greatest impact in Brazil was implemented in 2007, when the National Health Surveillance Agency (ANVISA) ${ }^{8}$ established a proposal to identify the specific types and nature of safety problems in health services in order to comply with WHO recommendations.

This same agency, in partnership with the Ministry of Health, launched the National Program for Patient Safety in April 2013, ${ }^{9}$ the purpose of which is to promote and support the implementation of initiatives directed to patient safety in different areas of care delivery, organization and the management of healthcare delivery, through the implementation of risk management and Patient Safety Centers in Brazilian health facilities.

One study was performed to systematize the recommendations of nursing professionals to improve patient safety and listed suggestions to improve procedures and working processes based on current patient safety principles such as: the establishment of protocols, risk barriers, patient identification, unit dose dispensing and double checking. There are also recommendations that involve professional behavior, such as dedication, commitment and awareness at work, respect and consideration. ${ }^{10}$ In regard to professional behavior, studies also stress that failures in communication when delivering care and problems with the content and reliability of information transferred through different settings have been identified as threats to patient safety. ${ }^{11}$

The services provided within the field of nursing play an important role in the search for quality in healthcare organizations, given the number of professionals working in these institutions and their responsibility in providing 24-hour care. $^{12}$

The combination of nursing competencies and training can be linked to the evolution of patients' conditions. One study showed a lower rate of mortality during hospitalizations for a variety of surgical patients in hospitals with a greater number of trained and qualified nurses. ${ }^{13}$ Regardless of one's level of education, qualification and a continuous search for tools to update knowledge and participation in actions that promote patient safety can play a role in the evolution of patients' conditions.

There were numerous strategies adopted at a world level in order to improve the context of safety in health services. Note that in 2005, PAHO's Human Resources for Health Unit created the International Network of Nursing and Patient Safety (RIENSP), in Concepción, Chile, with the 
objective to outline tendencies and priorities in the development of nursing related to "Patient Safety" and discuss cooperation and information exchange among nations and the need to strengthen evidence-based practice.

The challenges in the nursing field in regard to this topic include: the creation of Patient Safety Committees in healthcare facilities, composed of multidisciplinary teams in order to develop a safety culture within institutions and strengthening Nursing and Patient Safety Networks promoting rapid and effective communication of evidence, experiences and recommendations so that patient safety is ensured around the world. ${ }^{14}$

Networks are considered by the PAHO/ WHO to be important mechanisms that enable the exchange of information and experiences and the valorization of communication processes, in addition to being a constant exchange of knowledge among stakeholders. In this sense, a network is valued as an important strategy to support activities and implement effective public health actions. ${ }^{15}$

Even though improvements have been observed in terms of safety policies, people are still exposed to various risks when receiving healthcare.

This study's aim was to describe the experience of implementing the Brazilian Network for Nursing and Patient Safety (REBRAENSP), as well as the activities developed to disseminate a culture of patient safety in healthcare and teaching institutions.

\section{BRAZILIAN NETWORK FOR NURSING AND PATIENT SAFETY}

REBRAENSP was founded on May $14^{\text {th }}, 2008$, after the creation of RIENSP in November 2005, in meetings promoted by the Nursing Program of the PAHO's Human Resources for Health Unit. It is a strategy to establish connections, cooperation and synergy among people and institutions interested in the joint development of healthcare delivery, management, research, information and education, in order to contribute to patient safety.

REBRAENSP's work is structured in hubs and centers, the main purpose of which is to disseminate the importance of cultural changes and the implementation of a culture of patient safety in institutions. According to the one who conceived it, Silvia Helena de Bortoli Cassiani, REBRAENSP is based on the belief that networks imply solidarity, trust and respect for knowledge and experience.

It has been six year since REBRAENSP creation. It has had, since its creation, the involvement and participation of nurses from diverse regions of Brazil, who have enriched the discussions intended to clarify its objectives and develop its work plan, always in agreement with the RIENSP and the World Alliance for Patient Safety's objectives.

The network's first meeting included the presence of 15 nurses from various Brazilian regions. It is currently composed of more than 600 nurses, distributed in 24 centers or hubs in Brazilian states and cities (Figure 1) and is still increasing its coverage.

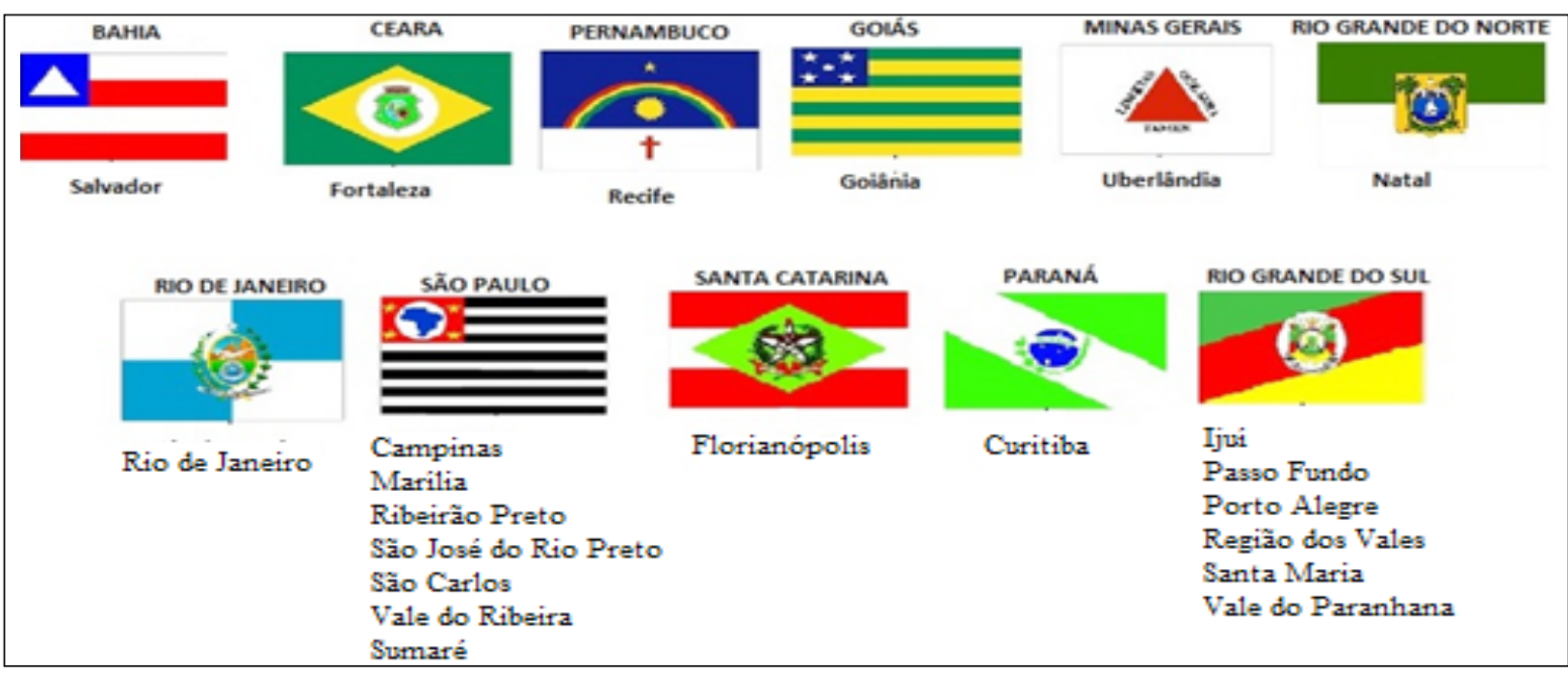

Figure 1 - Representation of the participating States that compose the Brazilian Network for Nursing and Patient Safety Hubs and Centers 


\section{Developed actions}

REBRAENSP encourages and supports the establishment of new Hubs and Centers through public speaking, ample dissemination through social networks and e-mail, as well as through a newly constructed website. ${ }^{16}$ This permits the dissemination of information and knowledge related to the nursing field and patient safety, aiming to disseminate all the activities developed by the Hubs or Centers and national and international policies related to the topic.

The logotype was created in 2008 to disseminate the name of the network nationally and internationally and associate its image with REBRAENSP (Figure 2).

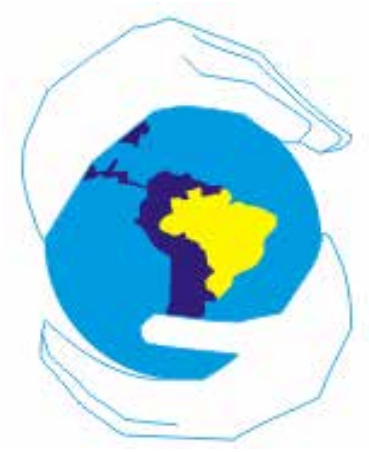

Figure 2 - Logotype of the Brazilian Network for Nursing and Patient Safety

Periodical meetings are held in different places to which the coordinators of REBRAENSP's hubs and centers are invited, while the participation of other nurses interested in becoming familiar with the network or becoming a member is also encouraged in these meetings to promote opportunities for them to meet personally.

Note that the Network's coordination and members participate in annual meetings promoted by RIENSP, which always take place at the same time the Pan-American Nursing Colloquiums are held.

These meetings enable members to identify and analyze potential barriers, interests, and priorities related to practice, management, investigation, and education in the field of nursing. Together, all the Hubs and Centers spread throughout Brazil, work with common goals and objectives, such as enhancing the development of multicenter investigations among members, sharing methodologies, and technological resources directed to the activities of care-delivery management, education, investigation, and technical cooperation related to nursing and patient safety.

The greatest challenge is to strengthen the presence of patient safety as a topic in nursing undergraduate and graduate programs and also in vocational/technical high school programs. Another challenge is to enable students to develop research that not only identifies the current context in Brazil related to patient safety, but also analyzes different strategies to introduce patient safety within teaching and care-delivery settings.

In 2013, the Network helped with the public consultation promoted by the Ministry of Health and Anvisa concerning the National Program of Patient Safety and safe surgery protocols, prevention of pressure ulcers, the practice of hand-washing in health services, falls prevention, patient identification, and safety in drug prescription, use and administration. A document directed to ANVISA was also developed in order to strengthen the participation of the Network in the implementation process of the National Program for Patient Safety. In this document, the Network states it's willingness to help and compose the group that will implement the Program and also develop educational material to help professionals deliver safe and quality care.

The creation of the REBRAENSP's website is considered an advancement, ${ }^{16}$ because the Hubs and Centers' coordinators can disseminate their actions through it and contribute to the dissemination of information related to national programs, material, and events, among other items.

The Hub in São Paulo, in partnership with the Patient Safety Program from the Regional Council of Nursing at São Paulo (CORENSP) and the board of the Brazilian Nursing Association in São Paulo (ABEn-SP), on April 6 $6^{\text {th }} 2010$ developed the "Declaration of the State of São Paulo Nursing for the Promotion of Patient Safety". The document was written to declare the commitment of the nursing association in São Paulo to develop actions promoting patient safety in the spheres of education, clinical practice, research and organizational culture, based on the profession's ethical and legal precepts. ${ }^{17}$

In 2010, It also published the booklet "10 steps toward patient safety"18 jointly with CORENSP. In 2011, new material was disseminated titled "Medication errors: definitions and prevention strategies". ${ }^{19}$ This kind of material is widely disseminated through social networks, websites, and meetings addressing patient safety. 
The book "Patient Safety Strategies: manual for healthcare workers", was developed in 2013 by the REBRAENSP team - the hub in Rio Grande do

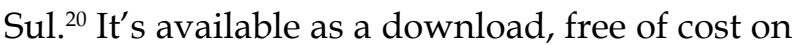
the Network's website.

\section{Work plan for 2014-2016}

One of the strategies adopted by the Network to operationalize actions is the development of national and local work plans. The REBRAENSP's work plans are outlined every three years based on recommendations contained in the RIENSP's work plan adapted to the Brazilian context. The objective is to promote the dissemination of the topic concerning nursing and patient safety among workers, health institutions and representatives of organized society.
This plan consist of six fields: nursing qualification, communication extended to communities, investigation and dissemination of knowledge, public policies, nursing services and the Network's expansion and strengthening. Each coordinator, together with the members of REBRAENSP's Hubs and Centers, must discuss and describe the plan according to the possibility of each one implementing it. The work plan, as well as its results, is represented by the coordinator or representative in REBRAENSP's six-month meetings and in local meetings held by each Hub or Center according to its schedule.

REBRAENSP's goals and respective strategies established for 2014 to 2016 are presented in table 1.

Table 1 - REBRAENSP's work plan for 2014 to 2016

\begin{tabular}{|c|c|}
\hline Goals & Strategies \\
\hline $\begin{array}{l}\text { Field 1: nursing education and patient } \\
\text { safety }\end{array}$ & $\begin{array}{l}\text { Mobilize schools' managers to include the topic of patient safety in } \\
\text { the curricula of nursing undergraduate, graduate programs and also } \\
\text { in vocational/technical programs. } \\
\text { Contribute to professional qualification that strengthens the National } \\
\text { Program for Patient Safety. }\end{array}$ \\
\hline $\begin{array}{l}\text { Field 2: communication extended to com- } \\
\text { munities and societies }\end{array}$ & $\begin{array}{l}\text { Promote events including discussions and reflections regarding pa- } \\
\text { tient safety. } \\
\text { Create on-going forums promoting multidisciplinary discussions } \\
\text { with the participation of members of community organizations } \\
\text { linked to the Municipal Councils of Health. } \\
\text { Develop and administer patient safety-related lectures and speeches. }\end{array}$ \\
\hline $\begin{array}{l}\text { Field 3: investigation and dissemination of } \\
\text { knowledge }\end{array}$ & $\begin{array}{l}\text { Conduct research addressing patient safety. } \\
\text { Maintain the website www.rebraensp.com.br updated. }\end{array}$ \\
\hline Field 4: public policies & Participation in the development of policies. \\
\hline Field 5: nursing services and patient safety & $\begin{array}{l}\text { Promote discussions and the dissemination of patient safety proto- } \\
\text { cols launched by the Ministry of Health: } \\
\text { - patient identification } \\
\text { - safe surgery } \\
\text { - falls prevention } \\
\text { - prevention of pressure ulcers } \\
\text { - safe drug administration } \\
\text { - hands washing } \\
\text { Contribute to the implementation of Patient Safety Centers in health- } \\
\text { care facilities. }\end{array}$ \\
\hline $\begin{array}{l}\text { Field 6: network expansion and strength- } \\
\text { ening }\end{array}$ & Create and develop new REBRAENSP hubs and centers. \\
\hline
\end{tabular}

\section{CONCLUSION}

It is believed that creating networks is the most efficacious strategy to establish the means in Brazil to disseminate and consolidate the patient safety culture in healthcare organizations, teaching and research institutions, non-governmental organizations, programs directed to patients and family members to strengthen the delivery of safe and quality nursing care. 
Within this sphere, participation that is marked by both excellence and responsibility is an ethical imperative of human care that is essential for a fulfilling life of individuals and societies.

The creation of state networks revealed Brazilian nurses to have a great interest in participating in those networks. The challenge is to produce more actions, more endeavors, and to increase the impact they have, especially in teaching institutions focused on the implementation of safe practices in health facilities. Successful actions, however, have already been implemented by REBRAENSP, as every year new advancements have been achieved in the dissemination of the importance of cultural changes and the implementation of safety culture for patients in institutions.

\section{REFERENCES}

1. World Health Organization. Summary of the evidence on patient safety: implications for research. Geneva (SW): World Health Organization; 2008.

2. Castañeda-Hidalgo H, Hernández RG, Salinas JFG, Zúñiga MP, Porras GA, Pérez AA. Percepción de la cultura de la seguridad de los pacientes por personal de enfermería. Ciencia Y Enfermeria. 2013; 19(2):77-88.

3. Wachter RM. Compreendendo a segurança do paciente. Porto Alegre: Artmed, 2010.

4. Kohn LT, Corrigan JM, Donaldson MS. To err is human: building a safer health system. Washington (US): National Academy Press; 2000.

5. Reis CT, Laguardi J, Martins M. Adaptação transcultural da versão brasileira do Hospital Survey on Patient Safety Culture: etapa inicial. Cad Saúde Pública. 2012; 28(11):2199-210.

6. Hemingway MW, O'Malley C, Silvestri S. Safety culture and care: a program to prevent surgical errors. AORN J. 2015; 101: 404-15.

7. Joint Commission for Patient Safety. World Alliance for Patient Safety [online]. 2008 [acesso 2013 Ago 01]. Disponível em: http:/ / www.ccforpatientsafety. org/30730/

8. Anvisa. Anvisa promove debate sobre segurança do paciente no Brasil. Ministério da Saúde. [online]. 2007 [acesso 2013 Ago 01]. Disponível em: http:/ / www.anvisa.gov.br/DIVULGA/ noticias/2007/171007.htm

9. Brasil. Portaria n. 529, de $1^{\circ}$ de Abril de 2013: Institui o Programa Nacional de Segurança do Paciente (PNSP) [online]. Brasília (DF): Ministério da Saúde; 2013 [acesso 2014 Jun 18]. Disponível em: http:/ / bvsms.saude.gov.br/bvs/saudelegis/gm/2013/ prt0529_01_04_2013.html

10. Mello JF, Barbosa SFF. Cultura de segurança do paciente em terapia intensiva: recomendações da enfermagem. Texto Contexto Enferm [online]. 2013 [acesso 2014 Jun 18]; 22(4):1124-33. Disponível em: http://www.scielo.br/scielo.php?script=sci_ arttext\&pid=S0104-07072013000400031

11. Dykes PC, Samal L, Donahue M, Greenberg JO, Hurley AC, Hasan $\mathrm{O}$, et al. A patient-centered longitudinal care plan: vision versus reality. J Am Med Inform Assoc. 2014; 21(6): 1082-90.

12. Caldana G, Gabriel CS, Bernardes A, de Pádua RX, Vituri DW, Rossaneis RA. Avaliação da qualidade de cuidados de enfermagem em hospital privado. Rev Eletr Enf [online]. 2013 [acesso 2015 Mai 20]; 15(4):915-22. Disponível em: http://www.uel. $\mathrm{br} / \mathrm{revistas} / \mathrm{uel} /$ index.php/seminabio/article/ viewFile/13913/13920

13. Agency for Healthcare Research and Quality (AHRQ). Patient Safety Network. Nursing and Patient Safety [página na Internet]. Rockville, MD. [atualizado 2015 Mar] [acesso em 2015 Mai 18]. Disponível em: http:/ / psnet.ahrq.gov/primer.aspx?primerID=22.

14. Silva, AEB. Segurança do paciente: desafios para a prática e a investigação em Enfermagem. Rev Eletr Enf [online]. 2010 [acesso 2015 Mai 19]; 12(3):422. Disponível em: http://www.fen.ufg.br/revista/ v12/n3/v12n3a01.htm.

15. Organização Pan-Americana da Saúde. Redes Colaborativas [online] [acesso 2013 Jul 05]. Disponível em: http:/ / www.paho.org/bra/index.php?option=com_content\&view $=$ article\&id $=1715 \&$ Itemid $=763$

16. Rede Brasileira de Enfermagem e Segurança do paciente. Quem somos [online]. 2013 [acesso 2013 Out 22]. Disponível em: http://www.rebraensp. com.br/quem-somos-8

17. Conselho Regional de Enfermagem do Estado de São Paulo (COREN-SP). Declaração da Enfermagem do Estado de São Paulo para a Promoção da Segurança do Paciente. [online] 2010 [acesso 2013 Nov 04]. Disponível em: http://portaldaenfermagem.com. br/downloads/declaracao.pdf

18. Conselho Regional de Enfermagem do Estado de São Paulo (COREN-SP). 10 Passos para a segurança do paciente. São Paulo: COREN-SP; 2010.

19. Conselho Regional de Enfermagem do Estado de São Paulo COREN-SP). Erros de medicação: definições e estratégias de prevenção. São Paulo: COREN-SP; 2011.

20. Rede Brasileira de Enfermagem e Segurança do Paciente. Estratégias para a segurança do paciente: manual para profissionais da saúde. Porto Alegre (RS): EDIPUCRS; 2013. 